\section{Regional-scale stand density management diagrams for Pyrenean oak (Quercus pyrenaica Willd.) stands in north-west Spain}

\author{
Javier Castaño-Santamaría ${ }^{(1-2)}$, Marcos Barrio-Anta ${ }^{(1)}$, Pedro Álvarez- \\ Álvarez ${ }^{(1)}$
}

Stand Density Management Diagrams are useful tools for designing and evaluating alternative density management regimes without the need of implementing any silvicultural action, and allowing the future stand conditions to be predicted prior to implementing management schedules. In this study, stand density management diagrams were developed for Pyrenean oak (Quercus pyrenaica Willd.) stands in north-west Spain by including data on stand volume, stand aboveground biomass, stand stem biomass and carbon pools. Data were obtained from Third National Forest Inventory plots $(n=1860)$. The large geographical area analyzed in this study was classified by provenance regions, which were compared in terms of biomass production in order to define areas with similar characteristics for use as management units. The comparisons identified 6 independent groups. Different stand-level models and the associated diagrams for the aforementioned stand variables were therefore developed for each group.

Keywords: SDMDs, Pyrenean Oak, Rebollo Oak, Biomass, Forest Management

\section{Introduction}

From the early days of forestry, one of the main aims of managers and researchers has been to estimate forest production and, more problematically, to predict productivity well before harvesting (e.g. Vanclay 1995). This can be achieved in two different ways: by considering environmental factors and by measuring stand parameters as indicators of the site and/or forest productivity (Assmann 1970). The second option has been found to be clearer, simpler and more reliable (Bengoa 2000).

Several studies published during the 1950 s and 1960s showed that stand development and forest productivity, including self-thinning and other competitive effects at tree and stand levels, are mainly influenced by stand density (Kira et al. 1953, Koyama \& Kira
1956, Shinozaki \& Kira 1956, Yoda et al. 1963). According to Jack \& Long (1996), forests can be managed by controlling only stand density. Conceptually, stand density management is the process of controlling resource competition through density regulation to meet specified management objectives (Newton 1997). However, at the operational level, density regulation consists in controlling the level of growing stock through initial spacing and/or subsequent thinning (Barrio-Anta \& Álvarez-González 2005).

Conversion of these specific management objectives into appropriate upper and lower levels of growing stock at stand level (expressed by the relative spacing index) is the most difficult step in designing a density management regime (Davis 1966, Clutter et

$\square$ (1) Grupo de Investigación en Sistemas Forestales Atlánticos (GIS-Forest), Departamento de Biología de Organismos y Sistemas, Escuela Politécnica de Mieres, Universidad de Oviedo, c/Gonzalo Gutiérrez Quirós S/N, 33600 Mieres, Asturias (Spain); (2) Unidad Mixta de Investigación en Biodiversidad, Universidad de Oviedo-CSIC-Principado de Asturias, c/Gonzalo Gutiérrez Quirós S/N, 33600 Mieres, Asturias (Spain)

@ Javier Castaño-Santamaría (castanojavier@uniovi.es)

Received: Nov 12, 2012 - Accepted: Jan 30, 2013

Citation: Castaño-Santamaría J, Barrio-Anta M, Álvarez-Álvarez P, 2013. Regional-scale stand density management diagrams for Pyrenean oak (Quercus pyrenaica Willd.) stands in north-west Spain. iForest 6: 113-122 [online 2013-03-05] URL: http://www.sisef.it/iforest/ contents/?id=ifor0880-006

Communicated by: Raffaele Lafortezza

al. 1983). According to Dean \& Baldwin (1996), the upper level is chosen to yield acceptable stand growth and individual tree vigor, while the lower level is chosen to maintain acceptable site occupancy. These must therefore be constrained within stand densities corresponding to the threshold of self-thinning and canopy closure (Dean \& Baldwin 1996). According to Jack \& Long (1996), the use of experimental thinning plots is the best option for determining the theoretical limits mentioned above. However, there are two serious disadvantages associated with the use of such plots (Dean \& Baldwin 1993): they are long-lasting and the results cannot be extrapolated accurately to forest stands with different site quality or management objectives.

One useful alternative approach for forest management decision-making is to use Stand Density Management Diagrams (SDMDs), which provide resource managers with an objective method of determining density control schedules (Newton 1997) and integrate relationships between density, stand structure, canopy dynamics and production efficiency, linking quantitative silviculture to population ecology, production ecology and biometrics (Jack \& Long 1996). The first diagrams were constructed by Ando (1962), who presented the competition and yield equations (based on stand density) and the self-thinning rule in a two-dimensional graphical format, which allowed thinning regimes to be derived in relation to management objectives. Several additions and modifications to the original modelling approach were proposed later on (e.g. Tadaki 1963, Aiba 1975, Drew \& Flewelling 1977, 1979, McCarter \& Long 1986), including the replacement of the original yield-density equations with empirical-based volume-density functions (e.g., Newton \& Weetman 1993) and the application of different relative density indexes (Newton 1997).

SDMDs are therefore graphical tools used in the design of silvicultural regimes in even-aged forests to illustrate the relationships between yield, density and mortality throughout all stages of stand development (Newton \& Weetman 1994). They also enable the simulation of several management regimes and the development of thinning schedules for a wide range of site qualities and management objectives (Castedo-Dorado et al. 2009), by using indices that relate the average tree size (e.g. volume, height or diameter) to density (e.g. number of trees per hectare - Barrio-Anta \& Álvarez-González 2005); this ensures that tree size is independent from site quality and stand age (McCarter \& Long 1986). SDMDs can also be used to control shrub development during early stages of stand development (e.g., Smith 1989), reduce stand susceptibility to 
pests (e.g., Long \& Shaw 2005) and optimize wildlife habitat (e.g., Sturtevant et al. 1996). However, their use is limited to a geographic range similar to that used for diagram calibration (Drew \& Flewelling 1977).

Quercus pyrenaica Willd. is a deciduous Mediterranean species, whose natural range is in south-western Europe (Ruiz de la Torre 2006). More specifically, its distribution area includes Portugal (62000 ha), Spain (660 000 ha), western France (34 500 ha) and northern Morocco (5 000 ha - Carvalho 2005). Spain and Portugal represent about $95 \%$ of the natural distribution area, so that the species can almost be considered as endemic to the Iberian Peninsula (Luis-Calabuig et al. 1994).

From a biogeographical point of view, $Q$. pyrenaica occupies an intermediate position between the central European Atlantic deciduous forests and Mediterranean xerophytic formations in the south of the Iberian Peninsula (Carvalho 2005), and its water and soil requirements are also intermediate between those of pure Atlantic (e.g., Quercus robur L.) and pure Mediterranean oaks (e.g., Quercus ilex L. - Costa et al. 2001).

Owing to the wide distribution of $Q$. pyrenaica, there is great variability among stands of this species in Spain in terms of silvicultural and ecological conditions (Adame et al 2008). Furthermore, traditional treatments pasture and forest fires have also affected $Q$. pyrenaica stands, further contributing to their variability (Allué 1994). As a result of these driving factors, Pyrenean oak stands are mainly found in the form of coppicemanaged stands or young forests, ranging from diminished stands with low densities to open woodlands with large diameter trees (Adame et al. 2006, Ruiz de la Torre 2006). The current extension of the species' range is lower than its potential distribution (Santa Regina 2000), probably because of the common replacement of Pyrenean oak stands by more productive pine plantations (Mesón García 1982). Nevertheless, species' covering in Spain doubled between the Second and the Third National Forest Inventories (period 1996-2006 - DGCN 2006), and some authors (e.g., Felicísimo et al. 2011) hypothesized that climate change might favor the expansion of its natural range.

According to Adame et al. (2006), management of oak forests is one of the greatest problems that forestry research is facing in Spain. It can be assumed that during at least the last 50 years, the average rotation length for Mediterranean coppices in Spain has varied between 20 and 30 years as a consequence of variations in the economy and the sociology of rural areas (Adame et al. 2006). The increased migration of rural populations to urban areas is leading to abandonment of traditional uses of oak (for firewood and charcoal), so that indirect uses of these fo- rests (i.e., silvopastoral uses, recreation, protection against erosion, regulation of water regime, etc.) and environmental functions (particularly their role of carbon sinks) have become more and more important (CastañoSantamaría \& Bravo 2012).

This has promoted interest in the structure, function and dynamics of these forest ecosystems, hitherto poorly known, despite being the fifth most important forest species in the Iberian Peninsula (Santa Regina 2000). As a result of this interest, a wide range of studies have been published in the last few decades. These studies have included the following aspects (amongst others): development of site index curves, in León (Torre 1994), La Rioja (Bengoa 2000), Castilla y León (Adame et al. 2006) and Galicia (DíazMaroto et al. 2010); fitting height-diameter models (Adame et al. 2008); modeling mortality (Adame et al. 2010); stand yield in terms of biomass (Allué \& San Miguel 1991, Carvalho 2005); and estimation of carbon stocks in Pyrenean oak stands, both in soils (Díaz-Pines et al. 2011) and in wood (Castaño-Santamaría \& Bravo 2012). However, only one stand-level model has been developed to date and this refers to the province of Leon (Bravo et al. 2011).

The aim of the present study was to develop practical SDMDs to provide a tool to help forest managers in the decision-making process (specifically those associated with the management of pure Pyrenean oak stands in north-west Spain) and to assess the aboveground wood volume. Forest managers can use these diagrams to plan different thinning regimes on the basis of current tree spacing and thus anticipate when the Pyrenean oak stand will be overcrowded. Foresters are usually unwilling to cut sufficient numbers of trees during thinning to allow the remaining trees to grow vigorously, and SDMDs will provide them with an objective means for determining the appropriate stand spacing.

\section{Material and Methods}

\section{Data}

Data used to develop the SDMDs for Pyrenean oak stands in NW Spain were obtained from the Third Spanish National Forest Inventory (NFI) plots (DGCN 2006) throughout the regions of Galicia, Asturias, Cantabria, La Rioja and Castilla y León. These consist of a systematic sample of permanent plots located on the nodes of a $1 \mathrm{~km}$ UTM square grid, comprising four sub-plots of radius of $5,10,15$ and $25 \mathrm{~m}$, with a minimum diameter at breast height threshold of 75 , 125, 225 and $425 \mathrm{~mm}$, respectively, and with a re-measurement interval of 10 years. Among all the NFI plots, those where Pyrenean oak was the dominant species (basal area proportion $>90 \%$ ), with a stand density higher than 100 trees ha ${ }^{-1}$, were selected $(\mathrm{n}=$ 1860). According to Bravo et al. (2008), the limit between open woodlands (in Spanish: dehesa) and Pyrenean oak forests (both high and coppice forests) is 100 trees ha' $\mathrm{h}^{-1}$.

Although the Pyrenean oak is widely distributed throughout the Iberian Peninsula, it is mainly found in the northwestern mountainous ranges (Costa et al. 2001). Indeed, the aforementioned regions account for more than $85 \%$ of the total species' covering in Spain (DGCN 2006). Within this large area many different soil and climatic conditions can be found (Sánchez-Palomares et al. 2008), including different bedrock substrates (granite, gneiss, quartzite, slate, etc.) and soils (Cambisols and rankers), although the most important is the common siliceous substrate (Jiménez-Sancho et al. 1998). Furthermore, the study area includes both Atlantic and Mediterranean regions that differ significantly in terms of rainfall and temperature (Costa et al. 2001, Sánchez-Palomares et al. 2008). The above variability is reflected in the presence of different plant species making up different geobotanical associations throughout the study area. The following species appear in Atlantic environments (e.g., Galicia and Asturias): accessory shrub species, such as Cytisus cantabricus, C. multiflorus, C. striatus, Erica arborea, E. cinerea, Calluna vulgaris, Genista florida sbsp. polygaliphylla, and herbaceous species, such as Melampyrum pratense, Linaria triornitophora, Holcus mollis, Deschampia flexuosa, Poa nemoralis (Díaz-González \& Fernández-Prieto 1987, Costa et al. 2001), which are replaced by others, such as Genista falcata, Cytisus purgans, Adenocarpus hispanicus, Satureja vulgaris, Arenaria montana, Geum sylvaticum, Veronica officinalis, Viola riviniana, $V$. odorata, Luzula forsteri, in Mediterranean environments (Mesón García 1982, Costa et al. 2001). Likewise, areas with intermediate conditions between Atlantic and Mediterranean environments have their own accessory species (Mesón García 1982). For more details about geobotanical associations and accessory species in Spanish $Q$. pyrenaica stands, see Mesón García (1982), Jiménez-Sancho et al. (1998), Costa et al. (2001) and Ruiz de la Torre (2006).

Several studies have delimited zones of similar characteristics within the wide geographical area considered in the present study, which could be used as management units. These zones vary from bioclimatic ecoregions (Elena Roselló 1997) to genetic provenance regions (Jiménez-Sancho et al. 1998). The difference between both categories is straightforward: an ecoregion is delimited by physiographic and climatic conditions (Elena Roselló 1997), while a provenance region is species-specific and reflects the region where species' populations share a similar phenotypic and/or genetic make-up, 
i.e., it may include a set of intermixable populations suffering similar selective pressures (Jiménez-Sancho et al. 1998). Therefore, at species level, geographic differentiation by provenance regions would be more reliable than differentiation by ecoregions.

Based of the above considerations, each plot was assigned to its respective provenance region by spatial data analysis, by use of a Geographical Information System (ESRI 2010). Fifteen provenance regions were identified within the database: (1) Galicia septentrional; (2) Galicia meridional; (3) Aliste-Maragatería; (4) Cordillera Cantábrica meridional; (5) Cordillera Cantábrica oriental; (6) Sistema Ibérico septentrional (7) Salamanca-Sayago; (8) Gata y Peña de Francia; (9) Gredos y Sierra de Ávila; (10) Valles del Tiétar y Jerte; (11) Norte de la Sierra de Guadarrama; (13) Sistema Ibérico meridional; (A) Rías Altas, (C) Asturias; and (D) La Liébana (Jiménez-Sancho et al. 1998).

Moreover, the following stand variables were calculated for each plot: number of trees per hectare $(N)$, quadratic mean diameter $\left(d_{\mathrm{g}}\right)$, dominant height $\left(H_{0}\right.$ - defined as the mean height of the 100 thickest trees per hectare), total stand volume $(V c c)$, stand stem biomass $\left(W_{\mathrm{f}}\right)$ and stand aboveground biomass $\left(W_{\mathrm{t}}\right)$. The total stand volume was calculated by summing the individual volumes and considering the expansion factors for each sub-plot, according to Bravo et al. (2002). Stand stem and stand aboveground biomass were calculated from the individual equations developed for these types of forests by Carvalho (2005 - eqn. $1, R_{\text {adj }}^{2}=$ $0.991, E=0.117 \mathrm{Kg}$ ) and Montero et al. (2005 - eqn. $2, R_{\text {adj }}^{2}=0.978, E=0.247 \mathrm{Kg}$ ), respectively, by a scaling-up approach. This method allows the prediction of stand biomass as the sum of the values predicted for individual trees (eqn. 1-2).

$$
\begin{gathered}
W_{f}=0.0218 \cdot\left(d^{2} h\right)^{1.012} \\
W_{t}=\exp \left(\frac{0.2473^{2}}{2}\right) \cdot \exp (-2.5969) \cdot d^{2.5345}
\end{gathered}
$$

where $W_{\mathrm{f}}$ is the stand stem biomass $(\mathrm{Mg}$ $\left.\mathrm{ha}^{-1}\right), W_{\mathrm{t}}$ the stand aboveground biomass $(\mathrm{Mg}$ $\left.\mathrm{ha}^{-1}\right), d$ is diameter at breast height $(\mathrm{cm}), h$ is total tree height $(\mathrm{m}), R_{\text {adj }}^{2}$ is the adjusted coefficient of determination, and $E$ is the mean bias

\section{Construction of the SDMDs}

SDMDs consist of a system of four equations and the relative spacing index $(R S)$ as basic components. The $R S$ is used to characterize the growing stock level and is calculated as the ratio, expressed as a percentage, between the average distance among trees and the dominant height. This index, which was first proposed for plantations by Hart in
1928 , was later referred to as the spacing index by Becking in 1954, and as relative spacing by Clutter et al. (1983) and Gadow \& Hui (1999). $R S$ is useful in stand density management because it is independent of site quality and stand age, except in very young stands, and because from a biological point of view, dominant height is one of the best criteria for establishing thinning intervals (Barrio-Anta \& Álvarez-González 2005). The association between dominant height growth and forest production adds further utility to these diagrams for forest management purposes (Barrio-Anta et al. 2006). As $Q$. pyrenaica stands are natural forests that are influenced by management (e.g., as a source of firewood), we assumed a triangular spacing between trees, so that $R S$ can be expressed as follows (eqn. 3):

$$
R S=\frac{\sqrt{20000 / N \sqrt{3}}}{H_{0}} \cdot 100
$$

where $R S$ is the relative spacing index (\%), $N$ is the number of stems per hectare, and $H_{0}$ is the dominant height $(\mathrm{m})$.

The first step in the construction of the SDMD is to fit the non-linear system of the following four equations (eqn. 4-7):

$$
\begin{aligned}
& d_{g}=\beta_{0} \cdot N^{\beta_{1}} \cdot H_{0}^{\beta_{2}} \\
& V=\beta_{3} \cdot d_{g}^{\beta_{4}} \cdot H_{0}^{\beta_{5}} \cdot N^{\beta_{6}} \\
& W_{f}=\beta_{7} \cdot d_{g}^{\beta_{8}} \cdot H_{0}^{\beta_{9}} \cdot N^{\beta_{10}} \\
& W_{t}=\beta_{11} \cdot d_{g}^{\beta_{12}} \cdot H_{0}^{\beta_{13}} \cdot N^{\beta_{14}}
\end{aligned}
$$

where $N$ is the number of stems per hectare, $d_{\mathrm{g}}$ is the quadratic mean diameter $(\mathrm{cm}), H_{0}$ is the dominant height $(\mathrm{m}), V$ the stand volume $\left(\mathrm{m}^{3} \mathrm{ha}^{-1}\right), W_{\mathrm{f}}$ the stand stem biomass $(\mathrm{Mg}$ $\left.\mathrm{ha}^{-1}\right), W_{\mathrm{t}}$ the stand aboveground biomass $(\mathrm{Mg}$ $\left.\mathrm{ha}^{-1}\right)$ and $\beta_{\mathrm{i}}(i=0,1, \ldots, 14)$ are the regression coefficients to be estimated.

Equations 4-7 together define a structurally simultaneous system of equations, where $N$ and $H_{0}$ are exogenous variables, $V, W_{\mathrm{f}}$ and $W_{\mathrm{t}}$ are endogenous variables and $d_{\mathrm{g}}$ is an endogenous instrumental variable. As there is correlation between the error components of the variables on the left-hand side and the right-hand side, the full information likelihood technique was applied to fit all the equations simultaneously by use of the ModeL procedure of SAS/ETS ${ }^{\circledR}$ (SAS Institute Inc. 2004)

\section{Comparisons of different regions}

Forest site productivity can be defined as the potential of a particular forest stand to produce aboveground wood volume, where the production unit refers to the site and the tree stand together (Skovsgarrd \& Vanclay 2007). Estimation of stem volume is important for mapping standing stock and for forest inventory purposes because it provides initial prediction of the amount of timber that could be commercially harvested (Wijaya et al. 2010), so that the maximum mean annual volume increment is usually considered a suitable measure of site quality. However, the volume attained by a stand at any given age can be affected by factors other than site quality, and unless these factors are controlled or adjustments are made to reflect their effects, differences in volumetric production among forest stands will bear little relationship to true differences in site quality. The principal confounding factors are stand density, species composition, genetics and cultural practices (Clutter et al. 1983).

Measurement of biomass is a parameter suitable for assessing the structure, functions and dynamics of forest ecosystems (Carvalho 2005, Montero et al. 2005) and for estimating carbon sequestration in a forest region over time (Houghton et al. 1990) because changes in biomass are linked with important outcomes in ecosystem functional characteristics and climate change. In fact, accurate assessment of biomass at local to regional and global scales becomes important for reducing the uncertainty of environmental processes and sustainability (Teller 1988). Therefore, biomass is considered better than volume for forest stands comparison purposes.

Moreover, estimation of the forest carbon (C) pool also provides an important indicator of sustainable forest management (well-managed forestland) in forest certification assessment (for instance in the Pan-European Criteria and Indicators for Sustainable Forest Management - MCPFE 2002). The carbon content of trees is usually calculated from wood volume equations $\left(\mathrm{m}^{3}\right)$ that include basic wood density $\left(\mathrm{Mg} \mathrm{m}^{-3}\right)$ and a conversion factor for the $\mathrm{C}$ concentration in dry biomass (\% C - Houghton et al. 1990). In this study, the carbon pool was calculated directly from stand aboveground biomass $\left(\mathrm{Mg} \mathrm{ha}^{-1}\right)$ and a specific conversion factor was applied for Pyrenean oak (0.475, according to Montero et al. 2005).

The Lakkis-Jones test (eqn. 8 - Khattree \& Naik 1995) and the non-linear extra sum of squares method (eqn. 9 - Bates \& Watts 1988) have been applied to the analysis of differences among geographic regions (e.g. Álvarez-González et al. 2005, Barrio-Anta et al. 2006, Adame et al. 2008). In the present study, both methods were used for the simultaneous detection of homogeneity among the regression coefficients of the stand aboveground biomass equation (eqn. 7) for the 15 previously defined provenance regions. The aforementioned comparative methods require fitting of reduced and full models. While the reduced model has the same set of parameters for all regions, the full model 
Tab. 1 - Goodness-of-fit statistics and results of the non linear extra sum of squares (F-value) and the Lakkis and Jones (Lakkis value) tests used to examine regional differences between the reduced and full models. Only the significant differences are shown. (PR): Provenance Re gions for Pyrenean oak in Spain (Jiménez-Sancho et al. 1998); (SSE): sum of squared errors; (df): degrees of freedom; (MSE): mean squared error; $\left(\mathrm{R}^{2}\right)$ : coefficient of determination for non-linear regression; $(\mathrm{n})$ : sample size. $\left({ }^{*}\right)$ : $\mathrm{p}<0.05$.

\begin{tabular}{|c|c|c|c|c|c|c|c|c|c|c|}
\hline \multirow{2}{*}{ Comparison } & \multicolumn{3}{|c|}{ Reduced model } & \multicolumn{3}{|c|}{ Full model } & \multirow{2}{*}{$\mathbf{R}^{2}$} & \multirow{2}{*}{$\mathbf{n}$} & \multirow{2}{*}{ F-value } & \multirow{2}{*}{$\begin{array}{c}\text { Lakkis } \\
\text { value }\end{array}$} \\
\hline & SSE & df & MSE & SSE & df & MSE & & & & \\
\hline PR_1 vs. PR_A & 1611.9 & 63 & 25.58 & 1609.4 & 60 & 26.82 & 0.9945 & 66 & $0.0314 *$ & $0.1036^{*}$ \\
\hline PR_C vs. PR_D & 28579.6 & 84 & 340.2 & 26134 & 81 & 322.6 & 0.9603 & 87 & $2.5266 *$ & $7.7826 *$ \\
\hline $\mathrm{PR} 2$ vs. PR 3 & 6676.6 & 239 & 27.93 & 6638.4 & 236 & 28.13 & 0.9916 & 242 & $0.4494 *$ & $1.3785 *$ \\
\hline $\mathrm{PR} 2$ vs. PR 7 & 3643.6 & 136 & 26.79 & 3460.2 & 133 & 26.01 & 0.9941 & 139 & $2.3489 *$ & $7.1763 *$ \\
\hline $\mathrm{PR} 33$ vs. PR_7 & 3656.8 & 168 & 21.77 & 3525.3 & 165 & 21.36 & 0.9835 & 171 & $2.0522 *$ & $6.2642 *$ \\
\hline $\mathrm{PR}^{-} 5$ vs. PR 6 & 103828 & 575 & 180.6 & 102804 & 572 & 179.7 & 0.9679 & 578 & $1.8693 *$ & $5.7293 *$ \\
\hline PR_5 vs. PR_11 & 3404.4 & 191 & 17.82 & 3380 & 188 & 17.98 & 0.9895 & 194 & $0.4513 *$ & $1.3923 *$ \\
\hline $\mathrm{PR}^{-} 5$ vs. $\mathrm{PR}_{-}^{-} 13$ & 1827.3 & 64 & 28.55 & 11769.8 & 61 & 192.9 & 0.9860 & 67 & $1.0267 *$ & $4.9898 *$ \\
\hline PR_6 vs. PR_11 & 103977 & 639 & 162.7 & 102536 & 636 & 161.2 & 0.9693 & 642 & $2.2275 *$ & $8.9597 *$ \\
\hline $\mathrm{PR}_{-}^{-} 6$ vs. PR_13 & 101065 & 512 & 197.4 & 100980 & 509 & 198.38 & 0.9667 & 515 & $0.1065 *$ & $0.4324 *$ \\
\hline $\mathrm{PR}-11$ vs. PR_13 & 1557.4 & 128 & 12.16 & 1556 & 125 & 12.45 & 0.9903 & 131 & $0.0277 *$ & $0.1179 *$ \\
\hline PR_8 vs. PR_ 9 & 5787.2 & 316 & 18.31 & 5644 & 313 & 18.03 & 0.9919 & 319 & $2.6479 *$ & $7.9950 *$ \\
\hline $\mathrm{PR}_{-}^{-} 8$ vs. PR_10 & 3957.3 & 257 & 15.39 & 3874.2 & 254 & 15.25 & 0.9921 & 260 & $1.8162 *$ & $5.5183 *$ \\
\hline PR 9 vs. PR_10 & 2252.7 & 100 & 22.52 & 2120.1 & 97 & 21.85 & 0.9912 & 103 & $2.0225 *$ & $6.2493 *$ \\
\hline
\end{tabular}

corresponds to different sets of parameters for each group and is obtained by expanding each parameter through an associated parameter and a dummy variable to differentiate the regions. The expressions are as follows (eqn. 8-9):

$$
\begin{gathered}
L=\left(\frac{S S E_{F}}{S S E_{R}}\right)^{\frac{n}{2}} \\
F_{\text {Chow }}=\left(\frac{S S E_{R}-S S E_{F}}{d f_{R}-d f_{F}}\right) \cdot \frac{d f_{F}}{S S E_{F}}
\end{gathered}
$$

where $L$ is the Lakkis-Jones value, $F_{\text {Chow }}$ is the non-linear sum of squares method value, $S S E_{\mathrm{F}}$ refers to the error sum of squares of the full model, $S S E_{\mathrm{R}}$ is the error sum of squares of the reduced model, $n$ is the number of data in the reduced model, and $d f_{\mathrm{R}}$ and $d f_{\mathrm{F}}$ are the degrees of freedom associated with the reduced and full model, respectively.

Based on the results of previous comparisons, we proceeded to refit the non-linear system of equations (eqn. 4-7) simultaneously for each group derived from the above analysis.

\section{SDMDs graphical representation}

The final step in the construction of the SDMDs consists of representing the isolines for the growing stock (expressed by the $R S$ ) and for the stand variables included in the stand-level model $\left(d_{\mathrm{g}}, V, W_{\mathrm{f}}\right.$ and $\left.W_{\mathrm{t}}\right)$.

Several different methods have been used to construct SDMDs (Jack \& Long 1996). In the system proposed here, dominant height was represented on the $x$-axis and the number of trees per hectare in logarithmic scale on the $y$-axis, following the method proposed by Barrio-Anta \& Álvarez-González (2005). The isolines were obtained by solving for $N$ in eqn. 3-7 (see Barrio-Anta et al. 2006, for more details). The quadratic mean diameter isolines were represented in the diagrams, using constant values for $d_{\mathrm{g}}$ and solving eqn. 4 for $N$. However, the isolines for eqn. 5-7 were represented in the diagrams by solving $d_{\mathrm{g}}$ in each equation with eqn. 4, assuming constant values for each variable and solving for $N$.

\section{Results and discussion}

Comparison among provenance regions

The significant values for the Lakkis-Jones and the non-linear extra sum of squares tests are shown in Tab. 1, along with the regression statistics of the reduced and full models of eqn. 7. The results revealed the formation of 6 independent groups, which are illus- trated in Fig. 1. The stand variable summary statistics (mean, maximum, minimum and standard deviation) are shown in Tab. 2 .

Group 1 is formed by provenance regions 1 and A (Galicia septentrional and Rías Altas); group 2 comprises Asturias and La Liébana provenance regions; group 3 consists of provenance regions 2,3 and 7 (Galicia meridional, Aliste-Maragatería and Salamanca-Sayago); group 4 is formed only by provenance region 4: Cordillera Cantábrica meridional; group 5 comprises Cordillera Cantábrica oriental, Sistema Ibérico septentrional, Norte de la Sierra de Guadarrama and Sistema Ibérico meridional provenance regions; and finally group 6 consists of provenance regions 8,9 and part of
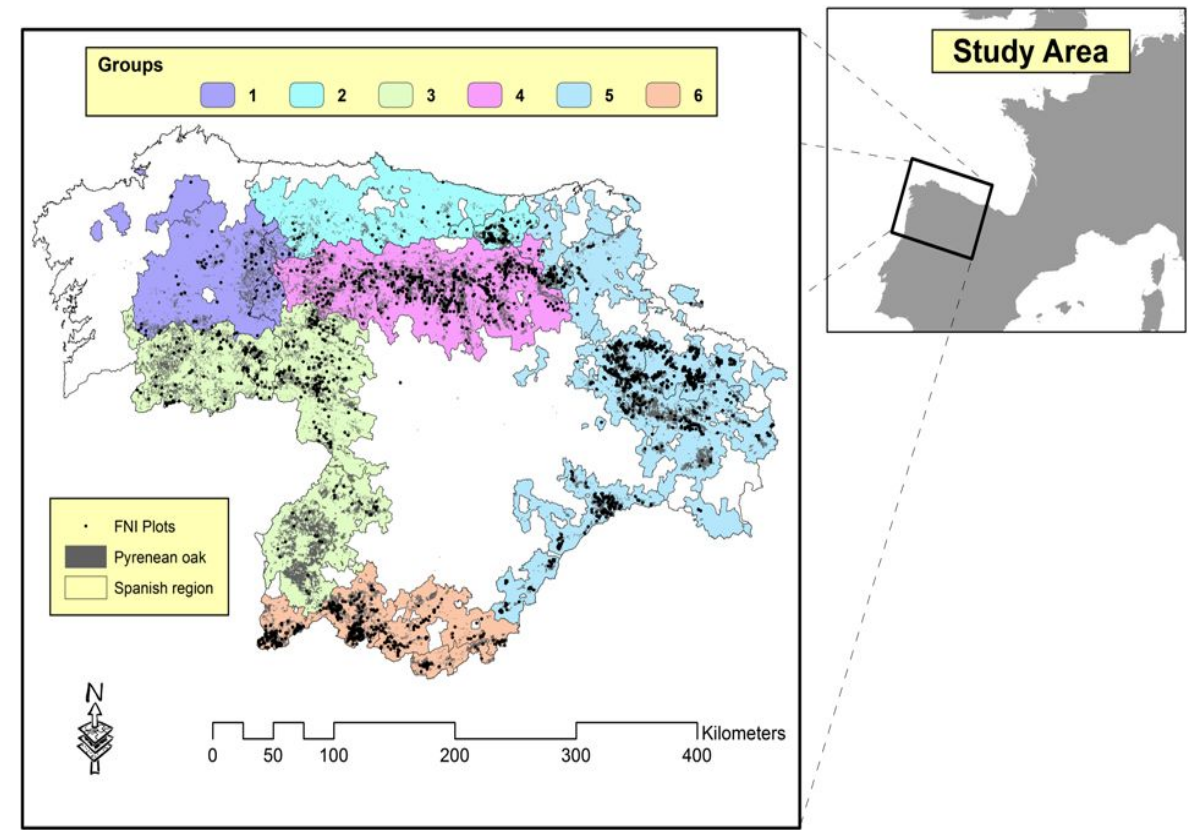

Fig. 1 - Natural distribution of Pyrenean oak in NW Spain and limit of the regions. 
Tab. 2 - Summary statistics for the dataset used. $(N)$ : number of stems per hectare; $(G)$ : basal area $\left(\mathrm{m}^{2}\right.$ ha $\left.{ }^{-1}\right) ;\left(d_{\mathrm{g}}\right)$ : quadratic mean diameter $(\mathrm{cm}) ;\left(H_{0}\right)$ : dominant height $(\mathrm{m}) ;(V)$ : stand volume $\left(\mathrm{m}^{3} \mathrm{ha}^{-1}\right) ;\left(W_{\mathrm{t}}\right)$ : stand aboveground biomass $\left(\mathrm{Mg} \mathrm{ha}^{-1}\right) ;\left(W_{\mathrm{f}}\right)$ : stand stem biomass $(\mathrm{Mg}$ $\left.\mathrm{ha}^{-1}\right) ;(\mathrm{SD})$ : standard deviation.

\begin{tabular}{|c|c|c|c|c|c|c|c|c|}
\hline Group & Value & $N$ & $G$ & $d_{\mathrm{g}}$ & $H_{0}$ & $V$ & $W_{\mathrm{t}}$ & $W_{\mathrm{f}}$ \\
\hline 1 & Mean & 535 & 14.07 & 19.14 & 11.94 & 67.94 & 78.27 & 55.37 \\
\hline \multirow{3}{*}{ (66 plots) } & Max & 2801 & 43.75 & 70.51 & 19.11 & 199.09 & 425.9 & 208.13 \\
\hline & Min & 106 & 0.64 & 8 & 3.5 & 1.7 & 1.9 & 0.66 \\
\hline & SD & 443 & 9.87 & 9.6 & 4.19 & 50.79 & 69.5 & 46.11 \\
\hline 2 & Mean & 568 & 17.62 & 21.82 & 10.21 & 77.79 & 110.47 & 58.98 \\
\hline \multirow[t]{3}{*}{ (87 plots) } & Max & 2649 & 50.28 & 56.53 & 21.09 & 288.04 & 365.78 & 275.93 \\
\hline & Min & 101 & 0.57 & 7.55 & 3 & 3.4 & 1.64 & 0.76 \\
\hline & SD & 481 & 11.43 & 10.47 & 3.5 & 54.28 & 87.44 & 48.73 \\
\hline & Mean & 604 & 10.84 & 16.56 & 10.05 & 46.61 & 54.89 & 37 \\
\hline \multirow{3}{*}{ (276 plots) } & Max & 3278 & 62.23 & 41.55 & 23 & 257.48 & 515.93 & 378.42 \\
\hline & Min & 103 & 0.6 & 7.75 & 2.57 & 1.18 & 1.75 & 0.8 \\
\hline & SD & 586 & 8.8 & 7.42 & 3.74 & 46.96 & 54.93 & 40.71 \\
\hline 4 & Mean & 758 & 10.92 & 13.42 & 8.82 & 41.06 & 50.39 & 31.64 \\
\hline \multirow[t]{3}{*}{ (381 plots) } & Max & 3038 & 44.51 & 34.22 & 17.29 & 209.35 & 307.17 & 181.42 \\
\hline & Min & 106 & 0.56 & 7.5 & 3 & 1.02 & 1.61 & 0.67 \\
\hline & SD & 601 & 9.48 & 4.75 & 2.89 & 43.01 & 52.35 & 34.23 \\
\hline \multirow{4}{*}{$\begin{array}{c}5 \\
\text { (709 plots) }\end{array}$} & Mean & 852 & 15.57 & 15.44 & 9.65 & 55.22 & 67.86 & 42.35 \\
\hline & Max & 3660 & 72.54 & 83.03 & 20.39 & 249.11 & 740.52 & 324.52 \\
\hline & Min & 104 & 0.56 & 7.5 & 1.5 & 0.99 & 1.61 & 0.59 \\
\hline & SD & 664 & 8.83 & 7.7 & 3.29 & 45.35 & 70.35 & 40.1 \\
\hline \multirow{4}{*}{$\begin{array}{c}6 \\
\text { (341 plots) }\end{array}$} & Mean & 683 & 12.38 & 17.04 & 10.87 & 52.67 & 60.13 & 42.22 \\
\hline & Max & 3788 & 72.54 & 48.68 & 23.17 & 258.84 & 341.3 & 237.51 \\
\hline & Min & 102 & 0.6 & 7.75 & 3.77 & 1.06 & 1.75 & 0.8 \\
\hline & SD & 587 & 7.88 & 6.64 & 3.27 & 44.52 & 46.19 & 37.01 \\
\hline
\end{tabular}

region 10 (Gata y Peña de Francia, Gredos y Sierra de Ávila and Valles del Tiétar y Jerte).

In view of these results, a specific SDMD was fitted for each group because there are 6 different types of Pyrenean oak stands - in terms of stand aboveground biomass - in the with those presented by Adame et al. (2008), who used the two ecoregions and six strata defined by Elena Roselló (1997) for the region of Castilla y León to compare Q.py-

Tab. 3 - Regional non linear regression coefficients obtained by simultaneous fitting of the four equations system. $\left(d_{\mathrm{g}}\right)$ : quadratic mean diameter $(\mathrm{cm}) ;(V)$ : stand volume $\left(\mathrm{m}^{3} \mathrm{ha}^{-1}\right) ;\left(W_{\mathrm{f}}\right)$ : stand stem biomass $\left(\mathrm{Mg} \mathrm{ha}^{-1}\right) ;\left(W_{\mathrm{t}}\right)$ : stand aboveground biomass $\left(\mathrm{Mg}\right.$ ha $\left.{ }^{-1}\right) ;(\mathrm{df})$ : degrees of freedom of error; (SSE): sum of squared errors; (MSE): mean squared error; ( $\mathrm{R}^{2}$ adj): adjusted coefficient of determination for non-linear regression. [*]: parameters are not significant at $\alpha=0.05$.

\begin{tabular}{|c|c|c|c|c|c|c|c|c|}
\hline Group & Variable & Parameter estimations & & & df & SSE & MSE & $R^{2} \operatorname{adj}(\%)$ \\
\hline 1 & $d_{\mathrm{g}}$ & $\beta_{0}=15.8691$ & $\beta_{2}=1.1035$ & & 63 & 1856.5 & 29.46 & 69.01 \\
\hline \multirow{3}{*}{ (66 plots) } & $V$ & $\beta_{3}=0.000187 \quad \beta_{4}=1.6537$ & $\beta_{5}=0.6226$ & $\beta_{6}=1.0190$ & 62 & 5526.3 & 89.13 & 96.55 \\
\hline & $W_{\mathrm{f}}$ & $\beta_{7}=0.000036 \quad \beta_{8}=2.0085$ & $\beta_{9}=0.9837$ & $\beta_{10}=0.9227$ & 62 & 424.1 & 6.84 & 99.68 \\
\hline & $W_{\mathrm{t}}$ & $\beta_{11}=0.000076 \quad \beta_{12}=2.5171$ & $\beta_{13}=[*]$ & $\beta_{14}=1.0250$ & 63 & 1611.9 & 25.58 & 99.47 \\
\hline 2 & $d_{\mathrm{g}}$ & $\beta_{0}=29.3902 \quad \beta_{1}=-0.3796$ & $\beta_{2}=0.8507$ & & 84 & 3328.4 & 39.62 & 63.89 \\
\hline \multirow{3}{*}{ (87 plots) } & V & $\beta_{3}=0.000407 \quad \beta_{4}=1.5811$ & $\beta_{5}=0.7358$ & $\beta_{6}=0.8978$ & 83 & 8561.7 & 103.2 & 96.5 \\
\hline & $W_{\mathrm{f}}$ & $\beta_{7}=0.000037 \quad \beta_{8}=2.0337$ & $\beta_{9}=0.973328$ & $8 \beta_{10}=0.9097$ & 83 & 3808.2 & 45.88 & 98.07 \\
\hline & $W_{\mathrm{t}}$ & $\beta_{11}=0.000108 \quad \beta_{12}=2.4728$ & $\beta_{13}=[*]$ & $\beta_{14}=1.0008$ & 84 & 28579.6 & 340.2 & 95.55 \\
\hline 3 & $d_{\mathrm{g}}$ & $\beta_{0}=14.4008 \quad \beta_{1}=-0.3024$ & $\beta_{2}=0.8473$ & & 273 & 4135.8 & 15.15 & 72.5 \\
\hline \multirow{3}{*}{ (276 plots) } & V & $\beta_{3}=0.000216 \quad \beta_{4}=1.4412$ & $\beta_{5}=1.0690$ & $\beta_{6}=0.9068$ & 272 & 37294 & 137.1 & 93.78 \\
\hline & $W_{\mathrm{f}}$ & $\beta_{7}=0.000021 \quad \beta_{8}=2.2209$ & $\beta_{9}=0.8317$ & $\beta_{10}=0.9744$ & 272 & 2628.1 & 9.66 & 99.42 \\
\hline & $W_{\mathrm{t}}$ & $\beta_{11}=0.000065 \quad \beta_{12}=2.5408$ & $\beta_{13}=0.0629$ & $\beta_{14}=1.0125$ & 272 & 6644 & 24.42 & 99.19 \\
\hline 4 & $d_{\mathrm{g}}$ & $\beta_{0}=6.2867 \quad \beta_{1}=-0.2183$ & $\beta_{2}=0.9844$ & & 378 & 2478.2 & 6.56 & 70.95 \\
\hline \multirow{3}{*}{ (381 plots) } & $\dot{V}$ & $\beta_{3}=0.000055 \quad \beta_{4}=1.9728$ & $\beta_{5}=0.8498$ & $\beta_{6}=0.9623$ & 377 & 16240.4 & 43.07 & 97.67 \\
\hline & $W_{\mathrm{f}}$ & $\beta_{7}=0.000021 \quad \beta_{8}=2.1536$ & $\beta_{9}=0.8776$ & $\beta_{10}=0.9847$ & 377 & 3418.8 & 9.07 & 99.23 \\
\hline & $W_{\mathrm{t}}$ & $\beta_{11}=0.000027 \quad \beta_{12}=2.7345$ & $\beta_{13}=[*]$ & $\beta_{14}=1.0841$ & 378 & 21908.9 & 57.96 & 97.88 \\
\hline 5 & $d_{\mathrm{g}}$ & $\beta_{0}=19.4353$ & $\beta_{2}=0.9321$ & & 706 & 15614.4 & 22.12 & 62.74 \\
\hline \multirow{3}{*}{ (709 plots) } & 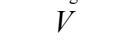 & $\beta_{3}=0.000235 \quad \beta_{4}=1.5583$ & $\beta_{5}=0.8679$ & $\beta_{6}=0.9187$ & 705 & 143498 & 203.5 & 90.1 \\
\hline & $W_{\mathrm{f}}$ & $\beta_{7}=0.000029 \quad \beta_{8}=2.0937$ & $\beta_{9}=0.8779$ & $\beta_{10}=0.9630$ & 705 & 12868.6 & 18.25 & 98.85 \\
\hline & $W_{\mathrm{t}}$ & $\beta_{11}=0.000105 \quad \beta_{12}=2.5062$ & $\beta_{13}=[*]$ & $\beta_{14}=0.9833$ & 706 & 106712 & 151.2 & 96.95 \\
\hline \multirow{4}{*}{$\begin{array}{c}6 \\
(341 \text { plots })\end{array}$} & $d_{\mathrm{g}}$ & $\beta_{0}=13.8398 \quad \beta_{1}=-0.2847$ & $\beta_{2}=0.8186$ & & 338 & 4271.3 & 12.63 & 71.38 \\
\hline & $V^{\circ}$ & $\beta_{3}=0.000053 \quad \beta_{4}=1.8773$ & $\beta_{5}=1.0161$ & $\beta_{6}=0.9464$ & 337 & 19907.3 & 59.07 & 97.02 \\
\hline & $W_{\mathrm{f}}$ & $\beta_{7}=0.000021 \quad \beta_{8}=2.1548$ & $\beta_{9}=0.9010$ & $\beta_{10}=0.9714$ & 337 & 3230.3 & 9.58 & 99.3 \\
\hline & $W_{\mathrm{t}}$ & $\beta_{11}=0.000063 \quad \beta_{12}=2.5907$ & $\beta_{13}=[*]$ & $\beta_{14}=1.0134$ & 338 & 6057.2 & 17.92 & 99.16 \\
\hline
\end{tabular}




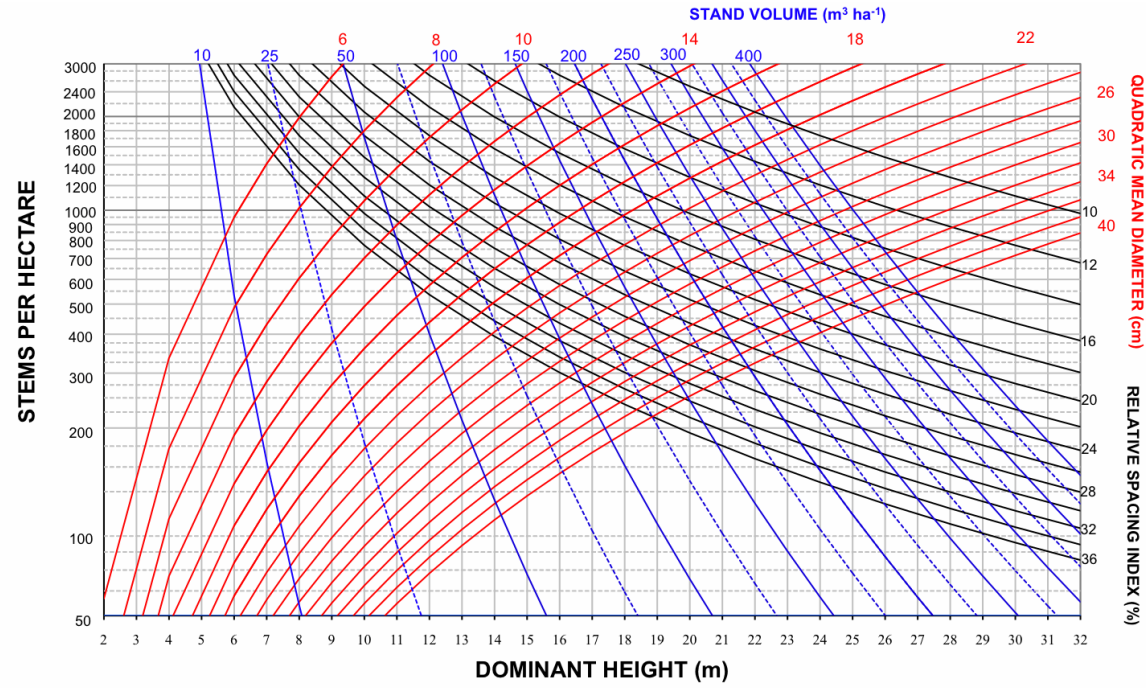

Fig. 2 - Stand density management diagram for even-aged Pyrenean oak stands in Region 1 in relation to stand volume $\left(\mathrm{m}^{3} \mathrm{ha}^{-1}\right)$.

renaica coppices characterized by medium to high densities (stand density over 200 trees per hectare), with regular diameter distribution and in which Pyrenean oak was the dominant species (basal area proportion over $90 \%$ ). A single height-diameter model was selected for both ecoregions and all strata, because no significant differences were detected between strata. Although the purposes of the statistical analyses are different, both use the same stand variables $\left(d_{\mathrm{g}}, H_{0}, \ldots\right)$, according to which 4 independent groups were observed in the same study area. Because of the wide range of ecological and genetic conditions present in the study area, the relationship between growth and yield is expected to vary from one zone to another (Huang et al. 2000). Mesón García (1982) differen- tiated Pyrenean oak stands in the same study area by establishing a four-zone classification according to the associated vegetation (which was very similar to that observed in the present study), ranging from humid-continental stands (corresponding to group 3 in the present study) to subhumid-continental stands (corresponding to group 5). In fact, differences among groups are more evident at the geobotanical level. For example, only group 1 includes the Vaccinio myrtilli-Querceto roboris $\mathrm{S}$. association, and it has Linario triornithophorae-Querceto pyrenaicae $\mathrm{S}$. in common with group 2, while group 3 includes Holco molli-Querceto pyrenaicae S., Genisto falcatae-Querceto pyrenaicae S. (both associations shared with group 6), and Genisto hystricis-Querceto rotundifoliae S.

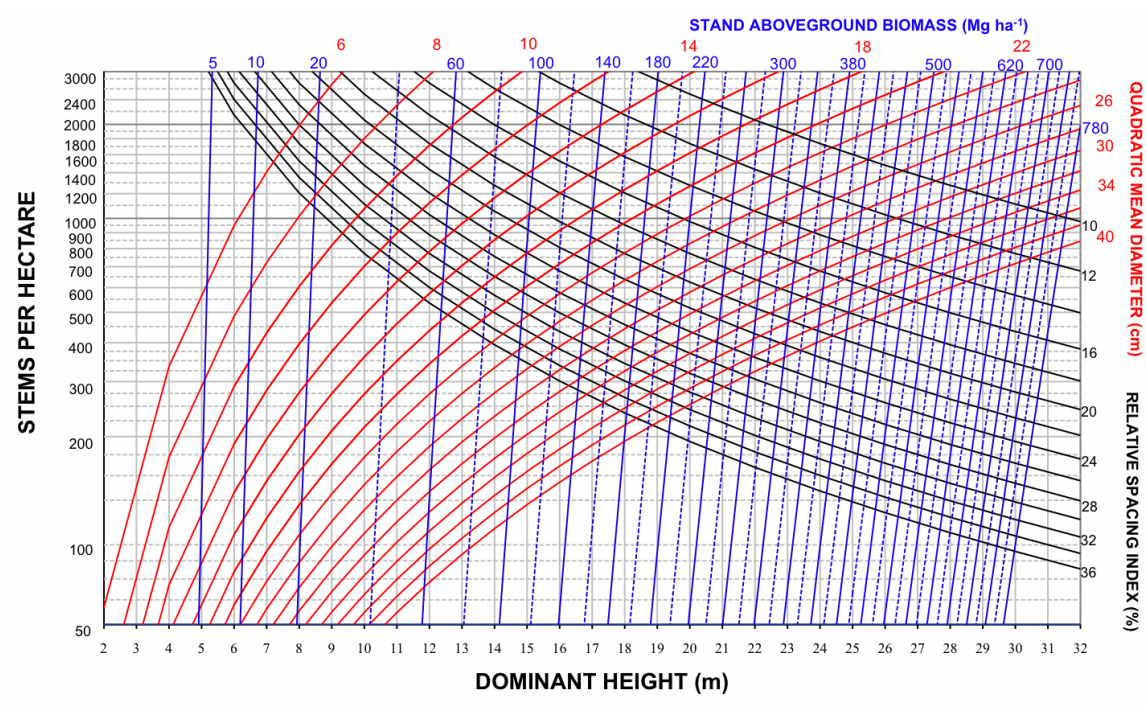

exclusively. Moreover, only group 4 includes Luzulo forsteri-Querceto pyrenaicae S. (shared with group 5), while Melampyro pratensis-Querceto pyrenaicae S., Festuco heterophyllae-Querceto pyrenaicae S. and Junipero thuriferae-Querceto rotundifoliae S. associations appear exclusively in group 5. The geobotanical associations appearing in group 6 are Genisto falcatae-Querceto pyrenaicae S. and Holco molli-Querceto pyrenaicae $\mathrm{S}$., as previously indicated (Mesón García 1982, Jiménez-Sancho et al. 1998, Costa et al. 2001, Ruiz de la Torre 2006).

\section{Construction of the diagrams}

The regression coefficients and statistics of the fitted models (eqn. 4-7) are shown in Tab. 3. All the parameter estimates were significant with $\mathrm{p}<0.0001$, except $\beta_{13}$, which was only significant in group 3 . Therefore, for the other 5 groups in which $\beta_{13}$ was not significant, the equations were re-fitted without $\beta_{13}$. The results of this re-fitting are reported in Tab. 3 .

All the equations provided a good level of accuracy, accounting for more than 62 and 90 per cent of the total variability for quadratic mean diameter and the three remaining variables in the system, respectively. The quadratic mean diameter equation always explained the least amount of the total variability (from $62.74 \%$ in group 5 to $72.50 \%$ in group 3 ), which is common for static stand-level models (Castedo-Dorado et al. 2009), while the stand stem biomass equation explained most of the total variability (from $98.07 \%$ in group 2 to $99.68 \%$ in group 1). The volume and the stand aboveground biomass provided intermediate results (from $90.10 \%$ in group 5 to $97.67 \%$ in group 4 , and from $95.55 \%$ in group 2 to $99.47 \%$ in group 1, respectively). Examination of the residuals revealed that all the regression models were unbiased with respect to the independent variables.

Therefore, four SDMDs for Pyrenean oak in each group of provenance regions were developed by superimposing the expected size-density trajectories on a bivariate graph with dominant height on the $x$-axis and number of stems per hectare on the $y$-axis; the values of relative spacing index were used to plot the isolines for each of the previously indicated variables $\left(d_{\mathrm{g}}, V, W_{\mathrm{f}}, W_{\mathrm{t}}, C-\right.$ Fig. 2 , Fig. 3, Fig. 4, Fig. 5). The range of values represented by the axes and the isolines was similar to the range of values included in the data used to construct the diagrams (Tab. 2).

On examination of these graphs, we noted that the biomass-related isolines $\left(W_{\mathrm{f}}, W_{\mathrm{t}}\right.$ and C) are arranged more vertically than the volume-related isolines in all groups. According to Pérez-Cruzado et al. (2011), this indicates that biomass-related isolines are less sensitive to changes in $N$ than volume-

Fig. 3 - Stand density management diagram for even-aged Pyrenean oak stands in Region 1 in relation to stand aboveground biomass $\left(\mathrm{Mg} \mathrm{ha}^{-1}\right)$. 
related isolines. This should be translated into larger exponents for $N$ in biomass equations. These results are consistent with the latter finding for aboveground biomass equations, as shown in Tab. 3 .

\section{Application of SDMDs in developing} thinning schedules and yield estimation

The schedule of thinning within the framework of the SDMD is determined by two factors (Barrio-Anta et al. 2006): the target stand status at the rotation age, and the upper and lower growing stock limits. The first factor can be defined by any logical combination of two of the following variables: dominant height, quadratic mean diameter, number of stems per hectare, stand volume, stand aboveground biomass, stand stem biomass or carbon pools in stand aboveground biomass at the rotation age, depending on the stand variable used to develop the diagram. On the other hand, selection of upper and lower growing stock limits often represents a silvicultural trade-off between maximum stand growth and maximum individual tree growth and vigour (Long 1985). Thus, the decision regarding appropriate levels of growing stock will reflect stand management objectives (e.g., Barrio-Anta et al 2006, Castedo-Dorado et al. 2009). The upper growing stock limit can be set higher than a determined relative spacing index value to avoid density-related mortality and to maintain an adequate live-crown ratio for good tree vigor. The lower growing stock limit can also be set to maintain adequate site occupancy, by using the relative spacing index. However, an alternative approach to setting a constant value of relative spacing index for the lower growing stock limit is to define the thinning interval in terms of dominant height growth, or to limit the maximum increment in the relative spacing index to guarantee stand stability after thinning (e.g., Pita 1991, cited in Barrio-Anta et al. 2006).

Once all the above variables were defined and the thinning schedule selected, and starting from the current stand status (defined by a combination of dominant height and stand density, for example), the sequence of thinning was plotted by the forward stair-stepping procedure until the target stand status was reached. Thinning segments were drawn parallel to the $y$-axis on the assumption that low thinning has no effect on dominant height. The post-thinning linear segments were also drawn parallel, in this case, to the $x$-axis, on the assumption that no mortality occurs between thinning intervals. Although both density-dependent and density-independent mortality may occur at any time, it seems reasonable to assume, for planning purposes, that no trees are lost between thinning operations (e.g., Amateis et al. 1997). In fact, such mortality rate is only important when thinning is not carried out (Castedo-

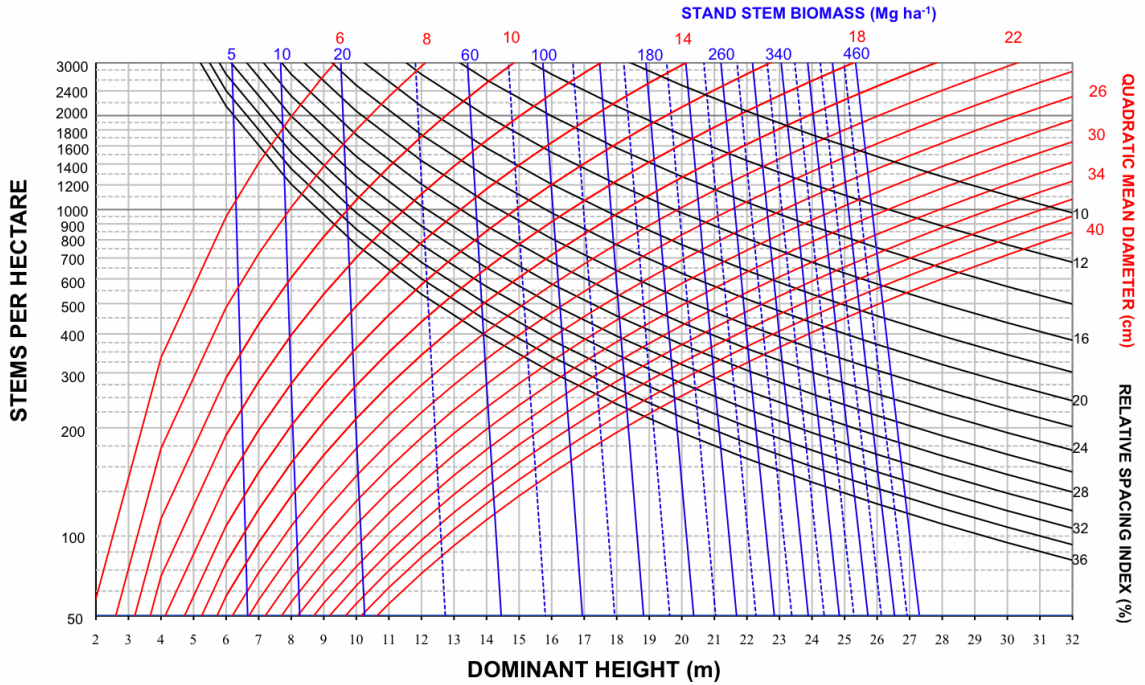

Fig. 4 - Stand density management diagram for even-aged Pyrenean oak stands in Region 1 in relation to stand stem biomass $\left(\mathrm{Mg} \mathrm{ha}^{-1}\right)$.
Dorado et al. 2009). However, to provide an estimate of the mortality rate, data from plots measured more than once would be necessary to calculate a mortality model (Jack \& Long 1996). The use of NFI data does not allow multiple measurements for estimating this model because of the data collection protocol involved (Bravo et al. 2002).

SDMDs also have other limitations, partly due to their basis as growth and yield tools (Jack \& Long 1996). Mack \& Burk (2005) enumerate some drawbacks of SDMDs, such as the lack of automation, the poor age and economic accounting, and the inflexible product yield reporting. However, not all of these drawbacks can be considered as such. For example, Mack \& Burk (2005) state that the lack of automation alone greatly limits the effective application of SDMDs because they can be tedious and cumbersome to use. A second weakness involves the economic analysis. Given that SDMDs estimate yield and not economic returns, it would be necessary to transfer yield information to an accompanying spreadsheet or similar application to estimate the income derived from the selected thinning schedule. Nowadays, these diagrams and the density relationships that occur therein can be easily computerized and prices can be assigned to each management approach with current software tools. However, it is true that SDMDs perform poorly in relation to product yield reporting, because they are typically single-product oriented, depicting yields for total volume, sawtimber volume or other product volumes, but

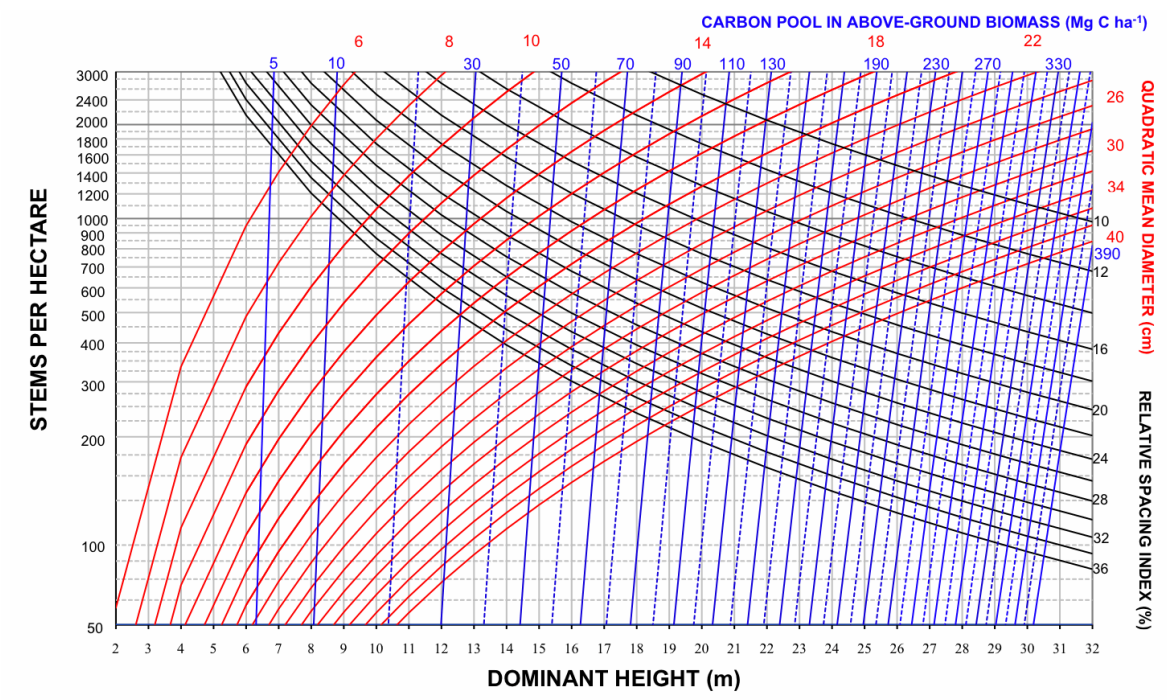

Fig. 5 - Stand density management diagram for even-aged Pyrenean oak stands in Region 1 in relation to carbon pool in aboveground biomass $\left(\mathrm{Mg} \mathrm{C}^{-1}\right)$. 


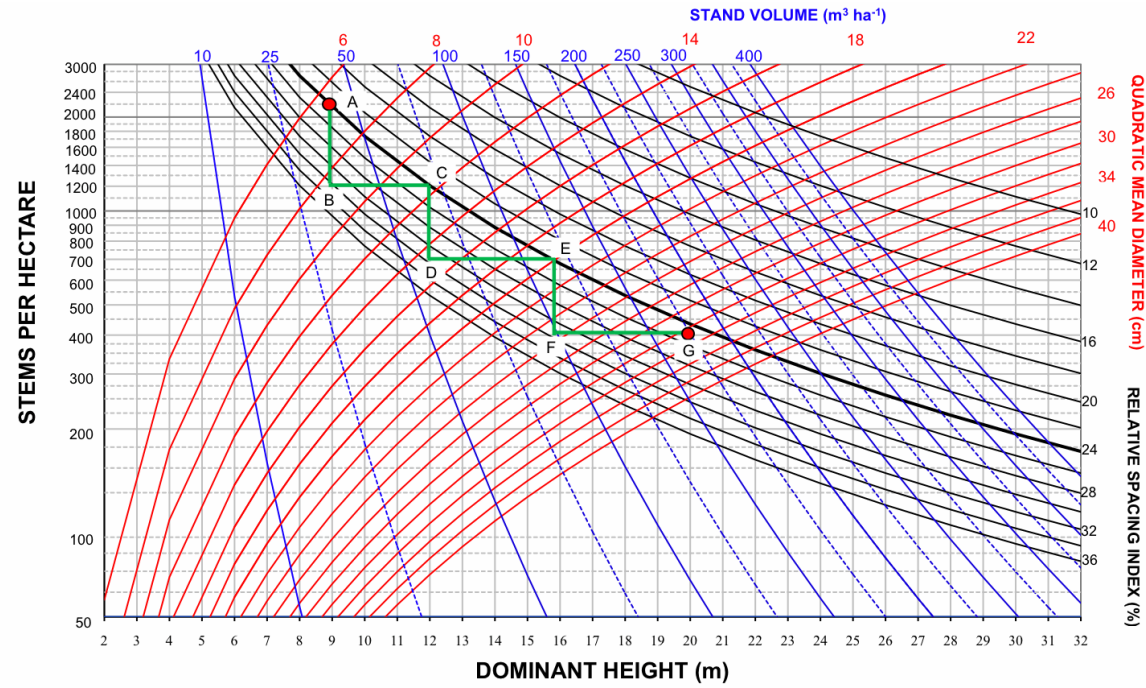

Fig. 6 - Stand density management diagram for even-aged Pyrenean oak stands in Region 1 and thinning sequence for a hypothetical management regime.

not combinations of these (Mack \& Burk 2005). On the other hand, the dynamics and management regimes described for the mean stand are not necessarily accurate or optimal for any particular stand (Drew \& Flewelling 1979). In fact, Vacchiano et al. (2008) consider that the computation of local site index tables is a priority for achieving more accurate stand growth predictions.

\section{A practical example}

The development of a Pyrenean oak stand in Region 1 under a particular management regime is illustrated in Fig. 6. The initial forest stand was defined by 2200 stems per hectare and a dominant height of $9 \mathrm{~m}$ in accordance with data from intermediate site quality Pyrenean oak stands in Portugal (Carvalho 2005), so that the lower growing stock limit was defined by a relative spacing

index value of $24 \%$. According to DíazMaroto et al. (2010), point A represents a stand of about 26 years for an intermediate site index (11 m height at 30 years) in Region 1 . The upper growing stock limit was defined by a maximum relative spacing index value of $32 \%$ to avoid shrub development, which is one of the major causes of fires in these stands (Allué 1994, Álvarez et al. 2009).

The management schedule consists of three thinning operations and, e.g., the target harvest age (point $\mathrm{G}$ in Fig. 6) was defined by a dominant height of $20 \mathrm{~m}$ and a quadratic mean diameter of around $30 \mathrm{~cm}$, and the thinning interval was based on a dominant height increment of $3 \mathrm{~m}$. Point $\mathrm{G}$ represents a stand of about 77 years for an intermediate site index in Region 1 (Díaz-Maroto et al. 2010). Using these values, the sequence of

Tab. 4 - Mensural data for the thinning sequence shown in Fig. 6. $(N)$ : number of stems per hectare; $\left(d_{\mathrm{g}}\right)$ : quadratic mean diameter $(\mathrm{cm}) ;(V)$ : stand volume $\left(\mathrm{m}^{3} \mathrm{ha}^{-1}\right) ;\left(W_{\mathrm{f}}\right)$ : stand stem biomass $\left(\mathrm{Mg} \mathrm{ha}^{-1}\right) ;\left(W_{\mathrm{t}}\right)$ : stand aboveground biomass $\left(\mathrm{Mg} \mathrm{ha}^{-1}\right) ;(C)$ : carbon pool in stand aboveground biomass $\left(\mathrm{Mg} \mathrm{C}^{-1}\right) ;(R S)$ : relative spacing index (\%).

\begin{tabular}{llcccc}
\hline Variable & Phase & $\begin{array}{c}\text { Thinning } \\
\text { (A and B) }\end{array}$ & $\begin{array}{c}\text { Thinning } \\
(\mathbf{C} \text { and D) }\end{array}$ & $\begin{array}{c}\text { Thinning } \\
(\mathbf{E} \text { and F) }\end{array}$ & $\begin{array}{c}\text { Harvest } \\
\text { (G) }\end{array}$ \\
\hline$N$ & Before thinning & 2200 & 1200 & 700 & 400 \\
$d_{\mathrm{g}}$ & After thinning & 1200 & 700 & 400 & \\
& Before thinning & 6.53 & 11.65 & 19.91 & 32.86 \\
& After thinning & 8.48 & 14.7 & 25.33 & \\
& Before thinning & 41.74 & 70.04 & 116.37 & 174.45 \\
$W_{\mathrm{f}}$ & After thinning & 34.64 & 59.35 & 97.97 & \\
& Before thinning & 16.48 & 39.94 & 93.34 & 192.05 \\
$W_{\mathrm{t}}$ & After thinning & 15.9 & 38.7 & 90.33 & \\
& Before thinning & 23.68 & 54.34 & 120.53 & 231.98 \\
& After thinning & 22.86 & 52.67 & 116.68 & \\
& Before thinning & 11.25 & 25.81 & 57.25 & 110.19 \\
& After thinning & 10.86 & 25.02 & 55.42 & \\
& Before thinning & 25.45 & 25.85 & 25.7 & 26.86 \\
\hline
\end{tabular}

three thinnings was plotted by the forward stair-stepping procedure (Fig. 6).

Total yield, aboveground biomass, stem biomass and carbon pools can be obtained directly for any point on the diagram, by using the volume, biomass and carbon isolines. For example, the volumes removed during the thinnings were $7.1,10.69$ and $18.4 \mathrm{~m}^{3} \mathrm{ha}^{-1}$, and the volume reached 174.45 $\mathrm{m}^{3} \mathrm{ha}^{-1}$ at the end of the rotation. The sum of these volumes represents an estimate of stand volume by this specific density management regime. Stand aboveground biomass, stand stem biomass and carbon pools in stand aboveground biomass were obtained in a similar way by using the corresponding SDMDs. Mensural data for this example of a thinning sequence are shown in Tab. 4 .

\section{Conclusions}

Forest species do not react equally throughout their distribution area to the same environmental conditions and forest interventions. Knowledge of the most appropriate practices for each forest type and delineation of forest stands responding in a similar way to the same intervention may eventually enable rational forestry management.

The stand-level static model developed can be used to determine stand volume, biomass and carbon stock for Pyrenean oak stands in NW Spain. This management tool is one of the most effective methods for the design, display and evaluation of alternative density management regimes in forest stands (Jack \& Long 1996, Castedo-Dorado et al. 2009) and can help foresters to check several indicators of sustainable forest management related to the growing stock. However, SDMDs are not intended as detailed growth and yield models.

In this paper we have only shown the diagrams for group 1 . However, the other diagrams are available upon request to authors.

\section{Acknowledgments}

JC performed the statistical analysis, wrote the original manuscript and incorporated the referees' and editor's suggestions in subsequent versions of the manuscript; MB conceived the study and PA helped to draft the manuscript. JC was in receipt of a Severo Ochoa Fellowship (cod. 09/111) from the Government of Asturias-FICYT. The Spanish Environmental Ministry contributed to this study by providing the digital format for the Pyrenean oak provenance regions. Special thanks to Dr. Christine Francis for revising the English of the manuscript. The valuable suggestions made by anonymous referees are also gratefully acknowledged.

\section{References}

Adame P, Cañellas I, Roig S, del Río M (2006). Modelling dominant height growth and site index curves for rebollo oak (Quercus pyrenaica 
Willd.). Annals of Forest Science 63: 929-940. doi: 10.1051/forest:2006076

Adame P, del Rio M, Cañellas I (2008). A mixed nonlinear height-diameter model for pyrenean oak (Quercus pyrenaica Willd.). Forest Ecology and Management 256: 88-98. - doi: 10.1016/j.foreco.2008.04.006

Adame P, del Rio M, Cañellas I (2010). Modeling individual-tree mortality in Pyrenean oak (Quercus pyrenaica Willd.) stands. Annals of Forest Science 67: 810. - doi: 10.1051/forest/2010046

Aiba Y (1975). Effects of cultural system on the stand growth of Sugi-plantations (Cryptomeria japonica) III. Estimate of the stem volume yield under actual stand density (H-D-p-V diagram). Journal of the Japanese Forestry Society 57: 6773. [in Japanese, English abstract].

Allué M (1994). Ordenación de masas de Quercus pyrenaica Willd. Actas de la reunión de Valsaín. Cuadernos de la Sociedad Española de Ciencias Forestales 1: 107-135.

Allué M, San Miguel A. (1991). Estructura, evolución y producción de tallares de Quercus pyrenaica Willd. en el centro de España. Investigación Agraria: Sistemas y Recursos Forestales 0: 35-48.

Álvarez R, Muñoz A, Pesqueira XM, García-Duro J, Reyes O, Casal M. (2009). Spatial and temporal patterns in structure and diversity of Mediterranean forest of Quercus pyrenaica in relation to fire. Forest Ecology and Management 257: 15961602. - doi: 10.1016/j.foreco.2009.01.016

Álvarez-González JG, Ruiz AD, Rodríguez Soalleiro RJ, Barrio M (2005). Development of ecoregion-based site index models for even-aged sands of Pinus pinaster Ait. in Galicia (northwestern Spain). Annals of Forest Science 62: 115-127. - doi: 10.1051/forest:2005003

Amateis RL, Burkhart HE, Jiping L (1997). Modeling survival in juvenile and mature loblolly pine plantations. Forest Ecology and Management 90: 51-58. - doi: 10.1016/S0378-1127(96) 03833-9

Ando T (1962). Growth analysis on the natural stands of Japanese red pine (Pinus densiflora Sieb. et. Zucc.) II. Analysis of stand density and growth. Bulletin of the Government Forest Experiment Station no. 210, Government of Japan, Tokio, Japan. [in Japanese, English summary]

Assmann E (1970). The principles of forest yield study. Studies in the organic production, structure, increment and yield of forest stands. Pergamon Press, Oxford, UK.

Barrio-Anta M, Álvarez-González JG (2005). Development of a stand density management diagram for even-aged pedunculate oak stands and its use in designing thinning schedules. Forestry 78: 209-216. - doi: 10.1093/forestry/cpi033

Barrio-Anta M, Balboa-Murias MA, Castedo-Dorado F, Diéguez-Aranda U, Álvarez-González JG (2006). An ecoregional model for estimating volume, biomass and carbon pools in maritime pine stands in Galicia (northwestern Spain). Forest Ecology and Management 223: 24-34. doi: 10.1016/j.foreco.2005.10.073

Bates DM, Watts DG (1988). Nonlinear regres- sion analysis and its applications. John Wiley and Sons, New York, USA.

Bengoa JL (2000). Curvas de calidad para Quercus pyrenaica en La Rioja. In: Actas del "Congreso de Ordenación y Gestión Sostenible de Montes" (Rojo Alboreca A, Díaz-Maroto Hidalgo IJ, Álvarez-González JG, Barrio-Anta M, Castedo-Dorado F, Riesco Muñoz G, Rigueiro Rodríguez A eds). Santiago de Compostela (Spain), 4-9 Oct 1999. Lugo, Spain. Tomo I, pp. 427-434.

Bravo F, Alvarez-Gonzalez JG, del Rio M, BarrioAnta M, Bonet JA, Bravo-Oviedo A, Calama R, Castedo-Dorado F, Crecente-Campo F, Condés S, Diéguez-Aranda U, S. Gonzalez-Martinez SC, Lizarralde I, Nanos N, Madrigal A, Martinez-Millán FJ, Montero G, Ordoñez C, Palahí $\mathrm{M}$, Piqué M, Rodríguez F, Rodríguez-Soalleiro R, Rojo A, Ruiz-Peinado R, Sanchez-Gonzalez M, Trasobares A, Vazquez-Pique J (2011). Growth and yield models in Spain: historical overview, contemporary examples and perspectivas. Forest Systems 20 (2): 315-328.

Bravo F, del Rio M, del Peso C (2002). El Inventario Forestal Nacional. Elemento clave para la gestión forestal sostenible. Fundación General Universidad de Valladolid-MMA, Madrid, Spain.

Bravo JA, Roig S, Serrada R (2008). Selvicultura en montes bajos y medios de Quercus ilex L., $Q$. pyrenaica Willd. y Q.faginea. In: "Compendio de Selvicultura Aplicada en España" (Serrada R, Montero G, Reque JA eds). MMA-INIA-Fundación Conde del Valle Salazar, Madrid, Spain, pp. 732.

Carvalho JP (2005). O Carvalho Negral. AgroUTAD, Vila-Real, Portugal.

Castaño-Santamaría J, Bravo F (2012). Variation in carbon concentration and basic density along stems of sessile oak (Quercus petraea (Matt.) Liebl.) and Pyrenean oak (Quercus pyrenaica Willd.) in the Cantabrian range (NW Spain). Annals of Forest Science 69: 663-672. - doi: 10.1007/s13595-012-0183-6

Castedo-Dorado F, Crecente-Campo F, ÁlvarezÁlvarez P, Barrio-Anta M (2009). Development of a stand density management diagram for radiata pine stands including assessment of stand stability. Forestry 82 (1): 1-16. - doi: 10.1093/ forestry/cpm032

Clutter JL, Fortson JC, Pienaar LV, Brister GH, Bailey RL (1983). Timber management: a quantitative approach. Krieger Publishing Co., Malabar, FL, USA

Costa M, Morla C, Sainz H (2001). Los bosques ibéricos. Una interpretación geobotánica $\left(2^{\text {nd }}\right.$ edn). Planeta, Barcelona, Spain.

Davis KP (1966). Forest management: regulation and valuation $\left(2^{\text {nd }}\right.$ edn). McGraw-Hill, New York, USA.

Dean TJ, Baldwin VC (1993). Using a density management diagram to develop thinning schedules for loblolly pine plantations. Research $\mathrm{Pa}$ per no. SO-275, Southern Forest Experiment Station, USDA Forest Service, New Orleans, LA, USA, pp. 8
Dean TJ, Baldwin VC (1996). Growth in loblolly pine plantations as a function of stand density and canopy properties. Forest Ecology and Management 82: 49-58. - doi: 10.1016/0378-1127 (95)03694-6

DGCN (2006). III Inventario Forestal Nacional 1996-2006. Dirección General de Conservación de la Naturaleza, Ministerio de Medio Ambiente, Madrid, Spain.

Díaz-González TE, Fernández-Prieto JA (1987). Asturias y Cantabria. In: "La vegetación de España" (Peinado M, Rivas-Martínez S eds). Universidad de Alcalá de Henares, Madrid, Spain.

Díaz-Maroto IJ, Fernández-Parajes J, VilaLameiro P, Barcala-Pérez E (2010). Site index model for natural stands of rebollo oak (Quercus pyrenaica Willd.) in Galicia, NW Iberian Peninsula. Ciencia Florestal 20: 57-68.

Díaz-Pines E, Rubio A, Montes F (2011). Aboveground soil $\mathrm{C}$ inputs in the ecotone between Scots pine and Pyrenean oak in Sierra de Guadarrama. Forest Systems 20: 485-495. - doi: $10.5424 /$ fs/20112003-11083

Drew TJ, Flewelling JW (1977). Some recent Japanese theories of yield-density relationships and their application to Douglas-fir plantations. Forest Science 23: 517-534.

Drew TJ, Flewelling JW (1979). Stand density management: an alternative approach and its application to Douglas-fir plantations. Forest Science 25: 518-532.

Elena Roselló R (1997). Clasificación biogeoclimática de España peninsular y balear. Ministerio de Agricultura, Pesca y Alimentación, Madrid, Spain.

ESRI (2010). ArcMap ${ }^{\mathrm{TM}}$, version 10.1. ESRI Inc., Redands, CA, USA.

Felicísimo AM, Muñoz J, Villalba CJ, Mateo RG (2011). Impactos, vulnerabilidad y adaptación al cambio climático de la biodiversidad española: 1- flora y vegetación. Oficina Española de Cambio Climático, Ministerio de Medio Ambiente y Medio Rural y Marino, Madrid, Spain.

Gadow KV, Hui GY (1999). Modelling forest development. Kluwer Academic Publisher, Dordrecht, The Netherlands.

Houghton JT, Jenkins GJ, Ephraums JJ (1990). Climate change. The IPCC scientific assessment. Cambridge University Press, Cambridge, UK.

Huang S, Price D, Titus SJ (2000). Development of ecoregion-based height-diameter models for white spruce in boreal forests. Forest Ecology and Management 129: 125-141. - doi: 10.1016/ S0378-1127(99)00151-6

Jack SB, Long JN (1996). Linkages between silviculture and ecology: an analysis of density management diagrams. Forest Ecology and Management 86: 205-220. - doi: 10.1016/S0378-1127 (96)03770-X

Jiménez-Sancho MP, Díaz-Fernández PM, Martín Albertos S, Gil Sánchez L (1998). Regiones de procedencia Ouercus pyrenaica Willd., Ouercus faginea Lam., Quercus canariensis Willd. Organismo autónomo Parques Nacionales, Dirección General de Conservación de la Naturaleza, Madrid, Spain. 
Khattree R, Naik DN (1995). Applied multivariate statistics with SAS Software. SAS Institute Inc., Cary, NC, USA.

Kira T, Ogawa H, Sakazaki N (1953). Intraspecific competition among higher plants. I. Competition-yield-density interrelationship in regularly dispersed populations. Journal of the Institute of Polytechnics, Osaka City University, vol. D4, pp. 1-16.

Koyama H, Kira T (1956). Intraspecific competition among higher plants. VIII. Frequency distributions of individual plant weight as affected by the interaction between plants. Journal of the Institute of Polytechnics, Osaka City University, vol. D7, pp. 73-94

Long JN (1985). A practical approach to density management. Forest Chronicle 23: 23-26.

Long JN, Shaw JD (2005). A density management diagram for even-aged ponderosa pine stands. Western Journal of Applied Forestry 20: 205 215 .

Luis-Calabuig E, Tárrega R, Calvo L, Díez C, Marcos E, Valbuena L, Alonso I (1994). Análisis fisionómico de los ecosistemas de Quercus pyrenaica Willd. en la cuenca del Duero. In: Acta de "Congreso Forestal Español" (Silva-Pando FJ, Vega Alonso G eds). Lourizán 1993. Ponencias y Comunicaciones, Xunta de Galicia, Vigo, Spain, Tomo I, pp. 405-409.

Mack TJ, Burk TE (2005). A model-based approach to developing Density Management Diagrams illustrated with Lake States Red Pine. Northern Journal of Applied Forestry 22: 117 123.

McCarter JB, Long JN (1986). A lodgepole pine density management diagram. Western Journal of Applied Forestry 1 (1): 6-11.

MCPFE (2002). Improved pan-European indicators for Sustainable Forest Management. Web site. [online] URL: http://www.mcpfe.org

Mesón García ML (1982). Tipificación forestal de los bosques españoles: los rebollares de Quercus pyrenaica Willd. Boletín Estatal Central de Ecología 21: 11-18.

Montero G, Ruíz-Peinado R, Muñoz M (2005). Producción de biomasa y fijación de $\mathrm{CO}_{2}$ por los bosques españoles. Monografías INIA, Serie forestal no. 13, MMA-INIA, Madrid, Spain. Newton PF (1997). Stand density management diagrams: review of their development and utility in stand-level management planning. Forest Ecology and Management 98: 251-265. - doi: 10.1016/S0378-1127(97)00086-8

Newton PF, Weetman GF (1993). Stand density management diagrams and their utility in black spruce management. Forest Chronicle 69: 421430.

Newton PF, Weetman GF (1994). Stand density management diagram for managed black spruce stands. Forest Chronicle 70: 65-74.

Pérez-Cruzado C, Merino A, Rodríguez-Soalleiro $R$ (2011). A management tool for estimating bioenergy production and carbon sequestration in Eucalyptus globulus and Eucalyptus nitens grown as short rotation woody crops in northwest Spain. Biomass and Bioenergy 35: 28392851. - doi: 10.1016/j.biombioe.2011.03.020

Ruiz de la Torre J (2006). Flora mayor. Organismo autónomo Parques Nacionales, Dirección General de Conservación de la Naturaleza, Madrid, Spain.

Sánchez-Palomares O, Roig S, del Río M, Rubio A, Gandullo JM (2008). Las estaciones ecológicas actuales y potenciales de los rebollares españoles. Monografías INIA, Serie forestal no. 17, MMA-INIA, Madrid, Spain.

Santa Regina I (2000). Biomass estimation and nutrient pools in four Quercus pyrenaica in Sierra de Gata Mountains, Salamanca, Spain. Forest Ecology and Management 132: 127-141. doi: 10.1016/S0378-1127(99)00219-4

SAS Institute Inc. (2004). SAS/ETS 9.1: user's guide. SAS Institute Inc., Cary, NC, USA.

Shinozaki K, Kira T (1956). Intraspecific competition among higher plants. VII. Logistic theory of the C-D effect. Journal of the Institute of Polytechnics, Osaka City University, vol. D12, pp. 69-82.

Skovsgarrd JP, Vanclay JK (2007). Forest site productivity: a review of the evolution of dendrometric concepts for even-aged stands. Forestry 81 (1): 13-31. - doi: 10.1093/forestry/cp- m041

Smith NJ (1989). A stand-density control diagram for Western red cedar, Thuja plicata. Forest Ecology and Management 27: 235-244. - doi 10.1016/0378-1127(89)90109-6

Sturtevant BR, Bissonette JA, Long JN (1996). Temporal and spatial dynamics of boreal forest structure in western Newfoundland: Silvicultural implications for marten habitat management. Forest Ecology and Management 87: 13-25. doi: 10.1016/S0378-1127(96)03837-6

Tadaki Y (1963). The pre-estimating of stem yield based on the competition density effect. Bulletin of the Government Forest Experiment Station no. 154, Government of Japan, Tokio, Japan. [in Japanese, English summary].

Teller A (1988). Biomass, productivity and wood waste evaluation in a spruce (Picea abies) forest (Strainchamps 1983). Commonwealth Forestry Review 7 (2): 129-148.

Torre M (1994). Degradación inducida por algunas prácticas agrarias tradicionales. El caso de los rebollares (Quercus pyrenaica Willd.) de la provincia de León. PhD thesis, Universidad Politécnica, Madrid, Spain.

Vacchiano G, Motta R, Long JN, Shaw JD (2008). A density management diagram for Scots pine (Pinus sylvestris L.): a tool for assessing the forest's productive effect. Forest Ecology and Management 255: 2542-2554. - doi: 10.1016/j.foreco.2008.01.015

Vanclay JK (1995). Modelling forest growth and yield: applications to mixed tropical forests. CAB International, Wallingford, UK.

Wijaya A, Kusnadi S, Gloaguen R, Heilmeier H (2010). Improved strategy for estimating stem volume and forest biomass using moderate resolution remote sensing data and GIS. Journal of Forest Research 21 (1): 1-12. - doi: 10.1007/ s11676-010-0001-7

Yoda K, Kira T, Ogawa H, Hozumi K (1963). Self-thinning in overcrowded pure stands under cultivated and natural conditions. Journal of Biology, Osaka City University, vol. D14, pp. 107129. 